ROCZNIKI HUMANISTYCZNE

Tom LXIX, zeszyt $12-2021$

DOI: https://doi.org/10.18290/rh216912-17

\author{
KHRYSTYNA KAZYMYRIV
}

\title{
UNOBVIOUS FUNCTIONS OF INSTRUMENTAL MUSIC IN HUMAN LIFE AND SOCIETY
}

To understand what music means in the life of a person and society, we must at least consider the issue: What is music? Music is an art that probably represents a mass of riddles that are discussed by scientists from various fields. This is inherent in its nature. Let us have a look at the discussion what music is.

According to the most common definitions music is organized sound, but this idea is not comprehensive, so researchers are constantly trying to clarify it. Therefore a number of different interpretations are formed. They vary from idealism through nominalism, realism, anti-realism to Platonism.

If we take a different direction and move towards generalization, we will see other interesting aspects. As physics tells us, sound is an oscillating motion of particles propagating in matter. Thanks to human physiology, people perceive these oscilations as sound in a rather narrow range. What will happen if we increase the frequency? At a certain stage we will see light. This is also oscillation, but this time we do not perceive it by hearing but by sight. Each color is a certain range of oscilations - in other words, colors are frequencies as well.

In different branches of physics we find many kinds of frequencies. The same thing happens when we try to look for frequencies (periodicity) in biology, chemistry, astronomy, mathematics, etc. In fact, different sciences are just

Dr KHRYSTYNA KAZYMYRIV - Przykarpacki Uniwersytet Narodowy im. Wasyla Stefanyka w Iwano-Frankiwsku; adres do korespondencji: ul. Szewczenki 57, 76018 Ivano-Frankivsk [вул. Шевченка, 57, 76018 м. Івано-Франківськ], Ukraina; e-mail: kazymyriv@gmail.com; ORCID: https://orcid.org/0000-0001-7757-7930.

Dr Khrystyna KaZYMyriv, Vasyl Stefanyk Precarpathian National University in IvanoFrankivsk; address for correspondence: 57 Shevchenko St., 76018 Ivano-Frankivsk [вул. Шевченка, 57, 76018 м. Івано-Франківськ], Ukraine; e-mail: kazymyriv@gmail.com; ORCID: https://orcid.org/0000-0001-7757-7930. 
different ways of covering the same system - the World. Human speech, a movement of microparticles, ebbs and flows, a change of day and night, heartbeat... Globally, we can think of all this as things of one range. That is, if we look at our world as a system, not limited by our definitions, we will see that music is like the language of the universe.

In this contest we need to mention the Pythagorean approach to the interpretation of music. He interprets it in a cosmological context: through the sound each person has the opportunity to perceive the unattainable structure of space. Moreover, this concept is complemented by the Pythagorean statement "Everything is a number", a number that contains an idea of the unity of the world, mind and music. (It is interesting to note how mathematics describes the material structure of the Universe, proportions and variety of flora and fauna, etc.)

According to Pythagorean ideas, the power of music was the isomorphic resonance: the relationship between musical intervals is correlated with the structure of the Universe at all levels. At this plane of morphological proportionality sound generates motion, which resonates in all living organisms. To some extent, such a model overcomes the distinction between body and mind, which is fundamental to Western philosophy.

An American musicologist Donald Jay Grout emphasizes that the word 'music' had a much wider meaning for the ancient Greeks than for us. In the doctrines of Pythagoras and his followers, music was integral to the numer, which acted as a key to the spiritual and physical universes. Thus, the system of musical sounds and rhythms, which finds expression in numbers, embodies the harmony of the universe and is directly related to it (Grout 31).

In later cosmologies the influence of Pythagorean doctrines is observed as well: Cicero (Scipio's Dream, 1st century BC), Ptolemy (Harmonics, mid-2nd century), Boethius (De institutione Musica, early 6th century), Gioseffo Zarlino (Istitutioni harmoniche, 1558); in the works of Robert Fludd (Utriusque cosmi maioris salicet et minoris metaphysica..., 1617), Johannes Kepler (Harmonices Mundi, 1619), and Athanasius Kircher (Musurgia Universalis, 1650). Specific calculations differ in particular cosmologies, but they stem from a single postulate: a direct comparison of cosmic, human and musical harmony.

Music is probably the most abstract art. And when we talk about abstraction we should keep in mind that in the global sense the ability of abstract thinking is the force that has ensured the development of mankind to current level. In this context perhaps the most interesting aspect would be to consider instrumental music, and especially "pure music", which has no non-musical 
accompaniment (a text, a program, illustrations, contexts etc.). Therefore, we could distinguish the effect of music as clearly as possible.

It is worth mentioning the role of music in human life. Obviously, in the first place, it brings pleasure, beauty and entertainment. But this is not the end of its functions. Since emotions are a major factor in the influence that music has on people, another question emerges: How and why does one react emotionally to pure music? Why do we often choose the kind of music that causes "negative" emotions such as sadness?

In fact, this is a philosophical problem of interpreting musical expression. Emotional indicators are psychological agents (they have emotions they want to express), but musical works are not. Why, then, do we say that a composition expresses emotions? This problem can be solved by distinguishing between expression, expressiveness, or expressivity. Expression is something that people do to express their emotions. Expressiveness is a property possessed by works of art. Due to its abstract nature and a special structure music can induce a specific psychological condition in a person: from calmness and balance to euphoria or even a state of altered consciousness. Examples of this effect can be traced in film music (which is in fact usually instrumental music). What happens if we remove music from a film? And what if we replace the music? By replacing the musical accompaniment we can completely change the perception of the whole story without changing the plot. That indicates that the emotional impact of music is very strong and often unconscious. Therefore, it is used at all times in various situations for very different purposes: to lift the spirits, to accompany a daily work, in meditations, religious rites, various celebrations, to lift the spirits in soldiers; it is used during political or other mass actions, to calm or specifically direct the emotions of the crowd, and so on.

The therapeutic effect of this art is built on the same principle. Music can relax, conserve, help to overcome anger, stress, and more. It can also be a significant help in overcoming the effects of a psychological trauma by returning to painful emotions in the safe artistic environment.

These reflections concerned the influence of music on our emotio. It is also worth the same in the field of ratio.

Music, especially pure music, has a significant impact on the development of thinking. Firstly, our brain likes logic and tries to fit the whole world into a system. Therefore, perception of music is a constant systematization of sounds, the search for understanding of their organization. Secondly, by listening to music a person searches or creates images, associations. Special emphasis 
should be placed on pure instrumental art, which has no verbal markers or stable images. It encourages people to search for its meanings and associations. All this stimulates the development of human cognitive abilities. It is interesting to note that in this context the most common contemporary pop music is simple in its structure and does not require much effort to understand it. But jazz and various alternative trends are not popular in societies. Therefore, it is interesting to compare the structure of society and the popularity of music that it consumes.

An incredibly important function of music is communication in the context of society or even humanity. However, how exactly does music do it yet being devoid of the verbal component? The musical environment of the folk genre is a complex system that is determined by many aspects: worldview, ideas, history, character of the nation. All this is expressed in music through characteristic modes, styles, consonances, instruments and so on. Each ethnic group has its own musical environment. This system gives a person a sense of belonging to the nation, the understanding of it, or rather, its sense, a distinction between "own" and "extraneous". In this system there occurs communication between ethnic groups, cultures, worldviews.

There is another thesis that cannot be ignored in the discussion about the role of this special art - music is probably the most abstract art. And when we talk about abstraction we should keep in mind that in the global sense the ability of abstract thinking is the force that has ensured the development of mankind to the contemporary level.

Despite the lack of a clear connection with our world, pure music is especially valuable due to its abstract nature. The musicologist Alan Goldman notes that in order to establish the special importance we attach to music it would not be enough to point out ways of expressing emotions. Because literature and the visual arts certainly do this with greater precision (the range of emotional states they are able to represent is beyond the reach of pure music). The true value of music, according to Goldman, lies in its ability to fully engage us in the study of the alternative world. After all, musical tones are experienced as independent of their material sources and constitute a virtual musical space (Goldman 39-40).

The foregoing considerations are in some ways very general. When we try to understand in a global sense what music is and what it means for us, it seems that we raise more questions than we receive answers. Nevertheless, it is important that this topic is discussed not only by philosophers, but also by music scholars and practicing musicians. After all, such a view, in my opinion, greatly enriches both musical practice and general understanding of music as an art. 


\section{BIBLIOGRAPHY}

Bonds, Mark E. Absolute music: The History of an Idea. Oxford UP, 2014.

Goldman, Alan. "The Value of Music." Journal of Aesthetics and Art Criticism, vol. 50, no. 1, 1992, pp. 35-44.

Grout, Donald J., and Claude V Palisca. A History of Western Music. 5th ed., W. W. Norton \& Company, 1996.

Xenakis, Iannis. Formalized Music: Thought and Mathematics in Composition. Indiana UP, 1971. 